\title{
IGF-binding proteins 3 and 4 are regulators of sprouting angiogenesis
}

\author{
Marchien G. Dallinga ${ }^{1} \cdot$ Yasmin I. Habani $^{1} \cdot$ Richelle P. Kayser $^{1} \cdot$ Cornelis J. F. Van Noorden ${ }^{1,2}(\mathbb{D}$. \\ Ingeborg Klaassen ${ }^{1,4}\left(\right.$ D) $\cdot$ Reinier O. Schlingemann ${ }^{1,3}$
}

Received: 17 April 2019 / Accepted: 18 February 2020 / Published online: 4 March 2020

(c) The Author(s) 2020

\begin{abstract}
Purpose We have previously identified insulin-like growth factor 2 (IGF2) and insulin-like growth factor 1 receptor (IGF1R) as essential proteins for tip cell maintenance and sprouting angiogenesis. In this study, we aim to identify other IGF family members involved in endothelial sprouting angiogenesis.

Methods Effects on sprouting were analyzed in human umbilical vein endothelial cells (HUVECs) using the spheroid-based sprouting model, and were quantified as mean number of sprouts per spheroid and average sprout length. RNA silencing technology was used to knockdown gene expression. Recombinant forms of the ligands (IGF1 and IGF2, insulin) and the IGF-binding proteins (IGFBP) 3 and 4 were used to induce excess effects. Effects on the tip cell phenotype were analyzed by measuring the fraction of $\mathrm{CD} 34^{+}$tip cells using flow cytometry and immunohistochemistry in a 3D angiogenesis model. Experiments were performed in the presence and absence of serum.

Results Knockdown of IGF2 inhibited sprouting in HUVECs, in particular when cultured in the absence of serum, suggesting that components in serum influence the signaling of IGF2 in angiogenesis in vitro. We then determined the effects of IGFBP3 and IGFBP4, which are both present in serum, on IGF2-IGF1R signaling in sprouting angiogenesis in the absence of serum: knockdown of IGFBP3 significantly reduced sprouting angiogenesis, whereas knockdown of IGFBP4 resulted in increased sprouting angiogenesis in both flow cytometry analysis and immunohistochemical analysis of the 3D angiogenesis model. Other IGF family members except INSR did not affect IGF2-IGF1R signaling.

Conclusions Serum components and IGF binding proteins regulate IGF2 effects on sprouting angiogenesis. Whereas IGFBP3 acts as co-factor for IGF2-IGF1R binding, IGFBP4 inhibits IGF2 signaling.
\end{abstract}

Keywords Angiogenesis · Tip cells · IGF2 · IGF binding proteins $\cdot$ Endothelial cells $\cdot$ Cultured cells $\cdot$ Endothelial growth factors

Electronic supplementary material The online version of this article (https://doi.org/10.1007/s11033-020-05339-0) contains supplementary material, which is available to authorized users.

Ingeborg Klaassen

i.klaassen@amsterdamumc.nl

1 Ocular Angiogenesis Group, Departments of Ophthalmology and Medical Biology, Amsterdam Cardiovascular

Sciences, Cancer Center Amsterdam, Amsterdam UMC, University of Amsterdam, Meibergdreef 9, Amsterdam, The Netherlands

2 Department of Genetic Toxicology and Cancer Biology, National Institute of Biology, Ljubljana, Slovenia

3 Department of Ophthalmology, University of Lausanne, Jules Gonin Eye Hospital, Fondation Asile des Aveugles, Lausanne, Switzerland

4 Ocular Angiogenesis Group, Department of Medical Biology, Amsterdam UMC, Meibergdreef 15, Room L3-154, 1105 AZ Amsterdam, The Netherlands

\section{Introduction}

Sprouting angiogenesis is a complex process that involves endothelial cell differentiation, proliferation and migration. It is initiated by an array of growth factors such as vascular endothelial growth factor (VEGF) [1]. We have recently reported that insulin-like growth factor 2 (IGF2) and insulin-like growth factor 1 receptor (IGF1R) are essential for sprouting angiogenesis, because they enable maintenance of the tip cells, the leading cells in vessel sprouts [2, 3]. Here, we have analyzed the role of other IGF family members in sprouting angiogenesis.

The IGF family consists of 2 ligands, IGF1 and IGF2, that can bind to 3 receptors, IGF1R, IGF2R and insulin receptor (INSR), which activates downstream signaling pathways such as the phosphatidylinositide 3-kinase 
(PI3K) and mitogen-activated kinase-like protein (MAPK) pathways, which are pro-angiogenic [4]. IGF1R and INSR can bind both IGF1 and IGF2, IGF2R can bind only IGF2 and inhibits its signaling [5, 6]. IGF1R and INSR both form homodimers as well as heterodimers that can bind both IGF ligands with similar binding affinity [7-9]. The IGF family also comprises 6 high-affinity and at least 4 low-affinity IGF-binding proteins (IGFBPs) that regulate bioavailability and degradation of IGF ligands [10]. For an overview of this complex interacting multicomponent network, we refer to Massoner et al. [11].

IGF2 and its family members have been linked to the process of angiogenesis in general [4, 12]. For example, levels of IGF1 and IGF2 in vitreous in the eye increase upon hypoxia, and IGF2 expression is upregulated in the growth phase of capillary hemangiomas [13-15]. Furthermore, experiments in mice have shown that IGF family members, including IGF1R, INSR and IGF2 are located in neovascular tufts in hypoxic retinas [14]. Although there are differences in activation of downstream signaling, a clear overlap for IGF1R and INSR signaling has been shown as well. This overlap includes pathways involved in angiogenesis such as the MAPK and PI3K pathways $[11,16]$, and it was recently published that INSR plays an important role in angiogenesis in tumors $[11,16,17]$.

However, specific information about the exact role of IGF family members in sprouting angiogenesis was lacking until recently, when we reported that IGF2 and IGF1R are involved in tip cell maintenance and sprouting angiogenesis by means of a local autocrine growth-regulating signaling axis [2]. We now present evidence that suggests that other IGF family members besides IGF2 and IGF1R are involved in this process as well.

Serum contains significant concentrations of both IGF ligands as well as IGFBPs. IGF1 is produced by hepatocytes in the liver, whereas IGF2 is produced in the liver but also in various other tissues such as bone and placenta $[18,19]$. Both ligands are transported in the circulation after complex formation with IGFBP3 and acid-labile subunit (ALS). The latter protein is also produced in the liver and reduces bioavailability and degradation of IGFs in the blood [20-24].

In the present study, we have determined the impact of serum on in vitro sprouting angiogenesis of HUVECs and studied the effects of IGFBP3 and IGFBP4, which are both present in significant concentrations in the circulation and therefore in serum. In the past, serum and vitreous levels of IGFBP3 have been positively correlated with angiogenesis and proliferative retinopathy [25], whereas IGFBP4 levels have been negatively correlated with angiogenesis [26-28]. Furthermore, in a previous study we noted that IGFBP4 is highly expressed in $\mathrm{CD} 34^{+}$tip cells when compared to nontip cells in vitro [29].
We show here that serum affects IGF2 and IGF1R functions in vitro, and that IGFBP3 and IGFBP4 are likely candidates for these effects, by regulating sprouting angiogenesis via IGF2 binding.

\section{Materials and methods}

\section{Cell cultures}

Primary human umbilical vein endothelial cells (HUVECs) were isolated from umbilical cords (obtained from the Department of Gynecology, Amsterdam UMC location AMC, Amsterdam, The Netherlands), as described previously [30]. HUVECs were cultured in M199 basal medium (Gibco, Grand Island, NY, USA) supplemented with $10 \%$ heat-inactivated human serum (obtained from the Department of Oncology, Amsterdam UMC location AMC, Amsterdam, The Netherlands), $10 \%$ fetal bovine serum (Gibco), and 1\% penicillin-streptomycin-glutamine (Gibco). HUVEC cultures were incubated with antibodies directed against CD31/PECAM-1 (1:100; eBioscience, Vienna, Austria) to check the purity of the endothelial cells. HUVECs were cultured in $2 \%$ gelatin-coated (Millipore, Billerica, MA, USA) T75 culture flasks at $37{ }^{\circ} \mathrm{C}$ and $5 \% \mathrm{CO}_{2}$. Experiments were performed with confluent HUVECs at passage 3 of at least 3 donors. Subjects gave informed consent for the use of tissues and/or serum and samples were stored anonymously. To determine the effects of increased extracellular protein concentrations, cells were treated with recombinant human IGF2, IGF1, IGFBP3, IGFBP4 (Prospec, Rehovot, Israel) or INS (Actrapid, Novo Nordisk, Sweden) as indicated. To determine the effect of serum proteins on IGF2-IGF1R interactions, we performed experiments in the presence and absence of serum. Addition of VEGF (R\&D Systems, Minneapolis, MN, USA) in a concentration of $25 \mathrm{ng} / \mathrm{mL}$ was necessary to reduce apoptosis and to maintain sprouting from spheroids in the absence of serum. Experiments in the presence of serum were performed without additional VEGF.

\section{siRNA knockdown}

HUVECs were transfected with $25 \mathrm{nM}$ of either a nontargeting small interfering RNA (siNT) or a gene-specific siRNA and $2.5 \mu \mathrm{g} / \mathrm{mL}$ Dharmafect 1 transfection agent (Dharmacon, Lafayette, CO, USA). Custom duplexes or company-selected smartpools were used as shown in Supplemental Table 1. Cells were transfected during $6 \mathrm{~h}$ using the reversed transfection method according to the manufacturer's instructions. Transfection efficiency was checked at the mRNA level (Supplemental Fig. 1a) and was considered acceptable when expression was reduced by at least $70 \%$ 
after $72 \mathrm{~h}$. To rule out cytotoxic effects by siRNA treatment, we performed MTT assays as described below. No negative effects on cell viability were observed (Supplemental Fig. 1c).

\section{Cell viability assay}

To test the effect of siRNA inhibition on cell viability, an MTT [3-(4,5-dimethylthiazol-2-zyl)-2,5-dipenyl-tetrazolium bromide] assay (Promega, Madison, WI, USA) was used, according to the manufacturer's instructions. Absorbance was measured photometrically at $570 \mathrm{~nm}$ using a microplate reader (VersaMax, Sunnyvale, CA, USA).

\section{RNA isolation and quantitative PCR}

Total RNA was isolated from cells using the TRIzol method according to the manufacturer's instructions (Invitrogen, Carlsbad, CA, USA). An amount of $1 \mu \mathrm{g}$ RNA was used for DNase-I treatment (amplification grade; Invitrogen) and reversely transcribed into cDNA using the Maxima First Strand cDNA Synthesis Kit (Thermo Scientific, Waltham, MA, USA). Real-time quantitative PCR (RT qPCR) was performed using a CFX96 real-time PCR detection system (Bio-Rad Laboratories, Hercules, CA, USA) as described previously [29]. Primer details are presented in Supplemental Table 1. NCBI BLAST confirmed the specificity of the primers. The presence of a single PCR product was verified by both the presence of a single melting temperature peak and detection of a single band of the expected size on agarose gels. Non-template controls were included to verify the method and the specificity of the primers. PCR products that did not show a single melting temperature peak were excluded from analysis. Ct values were converted to arbitrary absolute amounts $\left(2^{-\mathrm{Ct}} \times 1 \mathrm{E}^{12}\right)$ and expressed as fold change as compared to controls. Expression data was normalized to YWHAZ (tyrosine 3-monooxygenase/tryptophan 5-monooxygenase activation protein zeta) mRNA levels.

\section{Spheroid-based sprouting assay}

Spheroid experiments were performed with siRNA-transfected or untreated HUVECs. Transfected HUVECs were harvested after $48 \mathrm{~h}$, untreated cells were harvested when confluent. Cells (750 per spheroid) were seeded in methylcellulose (Sigma-Aldrich, Buchs, Switzerland) containing M199 medium and 2\% human serum to allow spheroid formation with the use of the hanging drop method [31, 32]. After $18 \mathrm{~h}$, the spheroids were embedded in collagen gels containing either $2 \%$ serum or VEGF-A $(25 \mathrm{ng} / \mathrm{mL})$ and when indicated exogenous IGF1 (30 ng/mL), IGF2 (50 ng/ $\mathrm{mL})$, insulin $(10 \mu \mathrm{M})$, IGFBP3 $(30 \mathrm{ng} / \mathrm{mL})$ or IGFBP4 (40 $\mathrm{ng} / \mathrm{mL}$ ), and were allowed to sprout for $24 \mathrm{~h}$. Images were taken using a phase-contrast microscope. Sprout numbers were counted using the NeuronJ plugin of ImageJ [33] and sprout length was measured in pixels and converted into $\mu \mathrm{m}$. For live microscopy, spheroids were incubated at $37^{\circ} \mathrm{C}$ in an atmosphere containing 5\% $\mathrm{CO}_{2}$ and imaged every $10 \mathrm{~min}$ for $24 \mathrm{~h}$ under an inverted phase-contrast microscope (Leica, Mannheim, Germany; 10× objective).

\section{Determination and selection of tip cells}

To determine the fraction of tip cells, HUVECs were harvested using TrypLE (Gibco), fixed in 4\% paraformaldehyde in PBS for 15 min at room temp and incubated with anti-CD34-phycoerythrin antibody (diluted 1:100; anti-CD34-PE; clone QBend-10; Thermo Scientific) for $30 \mathrm{~min}$ at room temp. Cells were analyzed flow cytometrically using a FACSCalibur (Becton Dickinson, Franklin Lakes, NJ, USA) and FlowJo 6.4.7 software (Tree Star, San Carlos, CA, USA). The FITC channel was used to detect autofluorescence. Non-stained and non-treated cells were used as negative controls.

\section{D angiogenic sprouting model combined with siRNA knockdown}

A 3D angiogenesis model was used as described previously [34]. Briefly, collagen type I (R\&D Systems) was patterned in the microfluidic channel, followed by a $24 \mathrm{~h}$ coating with fibronectin $(10 \mu \mathrm{g} / \mathrm{mL}$; Sigma-Aldrich) solution in PBS at $37{ }^{\circ} \mathrm{C}$ and $5 \% \mathrm{CO}_{2}$. Meanwhile, the HUVECs were first transfected with $25 \mathrm{nM}$ siNT or siIGF2 and $2.5 \mu \mathrm{g} / \mathrm{mL}$ DharmaFECT 1 transfection agent (Dharmacon). The cells were transfected for $6 \mathrm{~h}$ using the reversed transfection method according to the manufacturer's instructions and cultured in 12 -wells plates. The efficiency of $I G F 2$ knockdown was checked by qPCR in parallel cultures that were treated in similar medium conditions (Supplemental Fig. 1b) and was considered acceptable when expression was reduced by at least $70 \%$ after $72 \mathrm{~h}$. After $24 \mathrm{~h}$, the transfected HUVECs were seeded in one of the adjacent channels in a concentration of $2 \cdot 10^{7}$ cells/mL in EGM2 medium (PromoCell, Heidelberg, Germany). The cells were cultured for 3 days to form a confluent microvessel. Sprouting was induced by supplementing EGM2 media with VEGF $(50 \mathrm{ng} / \mathrm{mL}$; Peprotech, Rocky Hill, NJ, USA) and S1P $(0.5 \mu \mathrm{M}$; Sigma) for 2 days. The sprouting microvessels were fixed using $4 \%$ PFA for $15 \mathrm{~min}$, permeabilized for 15 min using $0.2 \%$ Triton-X100 and stained for nuclei using Hoechst (1:2000), F-actin using phalloidin (1:200) and anti-CD34 (1:50; clone MD34.2, Sanquin, Amsterdam, The Netherlands) at room temp. Images were acquired using a confocal microscope (Leica TCS SP8 DLS) using a 10X dry objective (NA 0.5) 
with a 2.0 digital zoom and images were acquired in the DAPI, AF488 and TexasRed channels. The line average was set at 6 and the imaging resolution at $2048 \times 2048$ pixels. Images were acquired from a total of 8 sites with $10 \%$ overlap per well. The max projections were stitched in LAS X (Leica Application Suite software) [35].

\section{Statistics and data correction}

To correct for differences between donors, data from flow cytometry and spheroid experiments were corrected using the Factor Correction program as described previously [36]. Statistical analysis was performed using a Student's t-tests. Triplicate experiments were performed in HUVEC cultures of at least 3 different donors.

\section{Results}

\section{Sprouting angiogenesis in vitro is dependent on IGF2 and is affected by serum components}

In our previous study, we found that IGF2 mRNA is enriched in $\mathrm{CD} 34^{+}$tip cells as compared to non-tip cells, and that knockdown of $I G F 2$ gene expression by siRNA leads to a reduction in the fraction of tip cells in endothelial cell cultures, and in reduced sprouting from spheroids [2]. Now, we verified this finding in a novel 3D angiogenesis model [34] after knockdown of IGF2 by siRNA. Whereas $\mathrm{CD} 34^{+}$tip cells were easily identified in sprouts after non-targeting siRNA (siNT) treatment, the existence of $\mathrm{CD} 34^{+}$tip cells was hardly found after knockdown of $I G F 2$ (Fig. 1). Sprouting did occur after IGF2 knockdown, but was reduced in number and length (Fig. 1e-h, i-l) as compared to siNT treated cells (Fig. 1a-d). In addition, cells
Fig. 1 Knockdown of IGF2 results in a reduced number of $\mathrm{CD} 34^{+}$tip cells in a $3 \mathrm{D}$ angiogenic sprouting model. HUVECs were transfected with non-targeting (siNT) siRNA (a-d) or siRNA against IGF2 (silGF2) (e-l). Angiogenic sprouts are stained for CD34 (green), F-actin (red) and nuclei (blue). Note the absence of $\mathrm{CD} 34^{+}$tip cells in siIGF2 treated cells. Magnifications are shown and indicated in the corresponding overview images. Long filopodial extensions are present in siNT treated cells $\left(\mathbf{d}^{\prime}\right)$, whereas filopodia-like extensions in siIGF2 treated cells were much shorter $\left(\mathbf{h}^{\prime}, \mathbf{l}^{\prime}\right)$. Representative images of triplicate experiments are shown. Scale bars, $100 \mu \mathrm{m}$ (overview a) and $20 \mu \mathrm{m}$ (magnification $\mathbf{d}^{\prime}$ )

with filopodial-like extensions were observed, but the length of these extensions was reduced (Fig. 1d', h', l').

In our previous study, experiments were performed in the presence of serum, which contains factors such as VEGF, bFGF, IGF1, IGF2 and IGFBPs, all of which may interfere with IGF2 signaling [4]. In the present study, we compared the effects of $I G F 2$ knockdown, and that of the addition of exogenous IGF2, on sprouting from HUVEC spheroids in the presence or absence of $20 \%$ serum to assess the effects of serum factors (Fig. 2). To maintain sprouting and reduce HUVEC apoptosis, it was necessary to add VEGF to HUVECs cultured in the absence of serum.

Spheroids sprouted less when treated with siIGF2. Knockdown of $I G F 2$ in the presence of serum resulted in a decreased number of sprouts by 1.8 -fold, whereas knockdown of $I G F 2$ in the absence of serum reduced the number of sprouts by 5.5-fold (Fig. 2a). Knockdown of IGF2 reduced sprout length to a similar extent in both conditions (1.3-fold versus 1.2-fold, respectively; Fig. 2b, c), whereas spheroids in serum-free conditions produced marginally longer sprouts than in the presence of serum.

To further explore the effects of serum components, we followed sprout formation from HUVEC spheroids by using live-cell imaging. We found that spheroids in the presence of serum and VEGF displayed a coordinated process of sprout initiation and elongation (Movie 1). Knockdown of IGF2 in the presence of serum resulted in failure of sprout formation: endothelial cells attempted to form sprouts, but rapidly returned into the spheroid (Movie 2). Together, these results suggest that IGF2 is necessary for initiation of sprouting, and that its effects are significantly affected by the presence of serum components.

Next, we determined the effects of exogenous IGF2 in the presence or absence of serum on sprouting angiogenesis. Addition of IGF2 resulted in an increased number of sprouts in the presence of serum (1.9-fold) and to a lesser extent in serum-free conditions (1.2-fold) (Fig. 2d). Sprout length was significantly reduced in the presence of serum and IGF2 (1.4-fold), whereas in the absence of serum sprouts were longer, independently of exogenous IGF2 (Fig. 2e). IGF2 increased the number of sprouts per spheroid in the absence of serum and in the presence of VEGF, without affecting sprout length (Fig. 2f). No cytotoxicity was observed after different periods in the presence of IGF2 in serum-free conditions (Supplemental Fig. 1d).

Together, our results suggest that IGF2 is an important player in angiogenic sprouting and that it is necessary for sprouting initiation of HUVEC spheroids, but that this depends on the presence of serum. Therefore, we suspected that serum components play a regulating role in the effects of IGF2 on angiogenesis, and we attempted to identify these serum components.


Fig. 2 Angiogenic sprouting is dependent on the presence of IGF2 and serum. HUVECs were cultured in the presence or absence of $20 \%$ serum and in the presence of either siNT or siIGF2 (a-c) or in the presence or absence of IGF2 (d-f). a Number of sprouts and $\mathbf{b}$ average length of sprouts $(\mu \mathrm{m})$ per spheroid after knockdown of $I G F 2$ in the presence or absence of serum; c corresponding representative images. Scale bars represent $200 \mu \mathrm{m}$. d Number of sprouts and e average length of sprouts $(\mu \mathrm{m})$ per spheroid cultured in the presence or absence of exogenous IGF2 in the presence or absence of serum and f corresponding representative images. Scale bars represent $200 \mu \mathrm{m}$. Data of sprout number and length are shown as the mean \pm standard deviation after factor correction. Medium of spheroids cultured in the absence of serum was supplemented with VEGF to maintain sprouting and to reduce EC apoptosis. $* \mathrm{P}<0.05$, ** $\mathrm{P}<0.01$, *** $\mathrm{P}<0.001$ as compared to control or siNT treatment using a Student's t-test $(\mathrm{n}=3)$ 


\section{IGFBP4 is an inhibitor of IGF2-induced sprouting}

To find possible interaction partners of IGF2 in angiogenesis, we determined mRNA expression of IGF family members using microarrays in $\mathrm{CD} 34^{+}$tip cells and nontip cells [29]. IGF1 is not expressed by HUVECs (Fig. 3), and will therefore be absent when HUVECs are cultured in the absence of serum, which indicates that in our HUVEC model, IGF1 is not necessary for sprouting angiogenesis. Expression of all receptors of the IGF family was significantly higher in $\mathrm{CD} 34^{+}$tip cells than in $\mathrm{CD} 34^{-}$cells (Fig. 3), whereas expression of IGFBP3 was similar in tip cells and non-tip cells, and expression of IGFBP4 was significantly higher in tip cells (Fig. 3).

IGFBP4 is an IGF-binding protein that inhibits sprouting [26]. To investigate whether IGFBP4 interacts with IGF2 and affects sprouting from spheroids, we performed siRNA-mediated knockdown of IGFBP4 in the presence or absence of exogenous IGF2 under serum-free conditions but in the presence of VEGF. Knockdown of IGFBP4 increased the number of sprouts but reduced the average sprout length both in the presence and absence of exogenous IGF2 (Fig. 4a, b). Simultaneous knockdown of IGFBP4 and $I G F 2$ greatly diminished the number of sprouts as compared to knockdown of IGFBP4 alone, but the number of sprouts was still slightly higher compared to knockdown of $I G F 2$ alone (Fig. 4c, d).

Exogenous IGFBP4 significantly reduced the number sprouts per spheroid (Fig. 4d). Addition of exogenous IGF2 increased the number of sprouts by 1.4 -fold in the absence

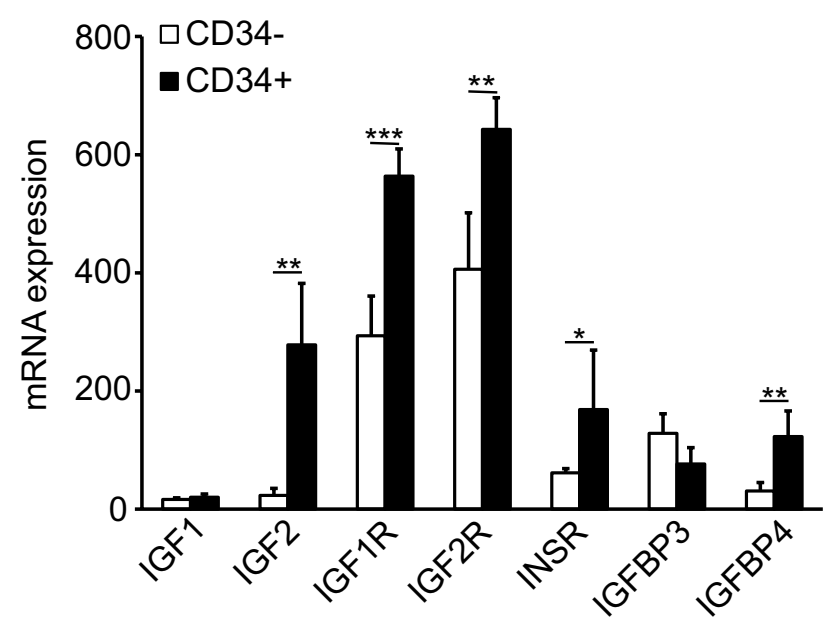

Fig. 3 mRNA expression of IGF family members in tip cells and nontip cells. Relative mRNA expression levels of $I G F 1, I G F 2, I G F 1 R$, $I G F 2 R, I N S R, I G F B P 3$ and IGFBP4 in CD34 ${ }^{+}$HUVEC tip cells and $\mathrm{CD} 34^{-}$HUVECs. Data are presented as normalized intensity values of mRNA expression as measured by microarray analysis as described previously [29]. $* \mathrm{P}<0.05$, ** $\mathrm{P}<0.01$, *** $\mathrm{P}<0.001$ as compared to control or siNT treatment using a Student's t-test $(\mathrm{n}=3)$ of IGFBP4, but not in its presence (Fig. 4e). Sprout length was not affected by exogenous IGFBP4 or IGF2 (Fig. 4f).

Together, these results show that IGFBP4 inhibits IGF2induced sprouting from spheroids.

\section{IGFBP3 is involved in sprouting angiogenesis and maintenance of the tip cell phenotype}

IGFBP3 is a serum component that has been associated with angiogenesis, with both pro- and anti-angiogenic roles reported [25]. To test whether it is involved in IGF2-induced sprouting, we performed siRNA-mediated knockdown of $I G F B P 3$ in the absence of serum but in the presence of VEGF, which resulted in a strong reduction in the number of sprouts as compared with treatment with siNT and to some extent in sprout length, irrespective of the presence of exogenous IGF2 (Fig. 5a-c). Addition of exogenous IGFBP3 did not significantly change the number of sprouts and did not affect sprout length (Fig. 5d, e). These results show that inhibition of IGFBP3 strongly reduces the number of sprouts per spheroid, whereas exogenous IGFBP3 did not induce additional sprouting from spheroids, similar to the effects of silencing IGF2 or addition of exogenous IGF2, respectively.

To study whether the effects of IGFBP3 on sprouting are due to direct effects on tip cells, we performed siRNAmediated knockdown of IGFBP3 in HUVEC cultures and measured the percentages of $\mathrm{CD} 34^{+}$tip cells, which were significantly decreased upon knockdown (Fig. 5f).

We conclude that IGFBP3 is an important co-factor in sprouting angiogenesis and tip cell maintenance.

\section{Inhibition of INSR, but not inhibition of IGF2R, reduces sprouting angiogenesis}

Previously, we have shown that knockdown of IGFIR reduces sprouting in vitro [2]. When studying the other receptors of the IGF family, we found that knockdown of INSR significantly decreased the number of sprout per spheroid but not their length, whereas knockdown of $I G F 2 R$ did not change the number or length of sprouts (Fig. 6a-c). HUVEC spheroids were cultured in the absence of serum but in the presence of VEGF, after treatment with siNT, siINSR or SIIGF2R.

The addition of exogenous IGF1 or INS also did not result in significant changes in sprouting from spheroids, as neither the number nor length of the sprouts changed (Fig. 6d, e).

\section{Discussion}

This study confirms the previously identified crucial role of IGF2 in sprouting angiogenesis, and shows that the IGF binding proteins IGFBP3 and IGFBP4 have positive and 

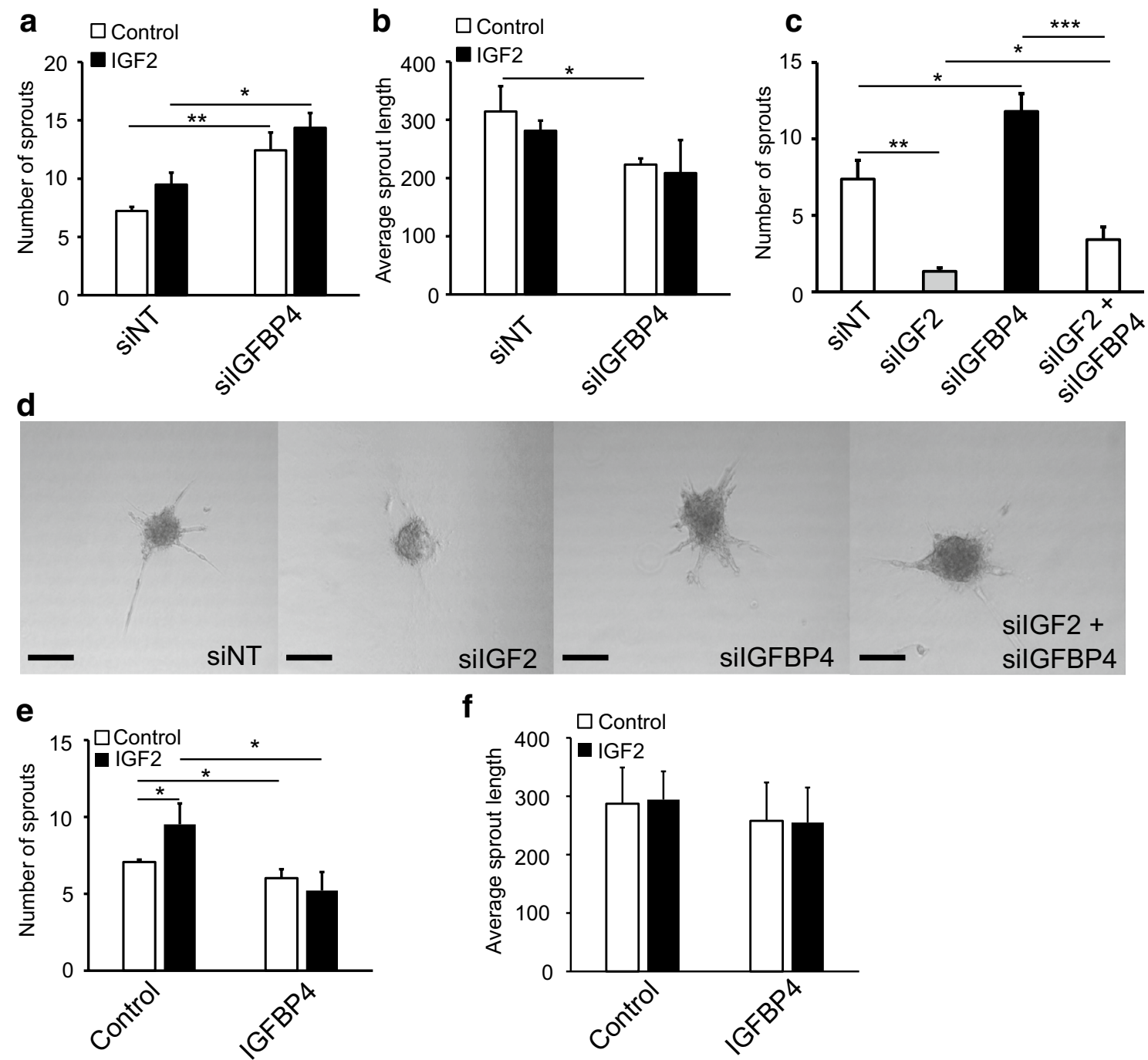

Fig. 4 IGFBP4 inhibits IGF2-induced sprouting angiogenesis. HUVECs were cultured in the absence of serum and in the presence of either siNT or siIGFBP4 and/or siIGF2 (a-d) or in the presence or absence of IGFBP4 and/or IGF2 (e-f). a Number of sprouts and b average length of sprouts $(\mu \mathrm{m})$ per spheroid after knockdown of $I G F B P 4$ in the presence or absence of exogenous IGF2. c Number of sprouts per spheroid after knockdown of IGFBP4 and/or IGF2. d Representative images of spheroids cultured in the absence of serum, but in the presence of VEGF and either siNT, siIGF2 and/or

negative regulatory roles in the function of IGF2 in sprouting angiogenesis, respectively. We have summarized our results in graphical form in Supplemental Fig. 2.

In a novel 3D angiogenesis model, we verified a role of IGF2 in sprouting angiogenesis. For the first time, we have applied this model in combination with siRNA-mediated knockdown. Previously we have reported this model in standard conditions [37], showing CD34-specific staining of endothelial tip cells. In siNT treated cells, a similar staining of CD34 was found, whereas in cells treated with siIGF2, CD34 staining was virtually absent. Although sprouting
siIGFBP4. Scale bars represent $200 \mu \mathrm{m}$. e Number of sprouts and $\mathbf{f}$ average length of sprouts $(\mu \mathrm{m})$ per spheroid in the presence and absence of exogenous IGFBP4 and/or exogenous IGF2. Medium of the spheroids was supplemented with VEGF to maintain sprouting and to reduce EC apoptosis. Data of sprout numbers and length are shown as the mean \pm standard deviation after factor correction. * $\mathrm{P}<0.05, * * \mathrm{P}<0.01, * * * \mathrm{P}<0.001$ as compared to control or siNT treatment using a Student's t-test $(\mathrm{n}=3)$

was still occurring after IGF2 knockdown, it was reduced in number and length. Knockdown efficiency is difficult to check in this model, but showed more than $80 \%$ reduction in $I G F 2$ mRNA levels in parallel culture plates in similar experimental conditions. Together these experiments show additional evidence for the important role of IGF2 in sprouting angiogenesis.

The purpose of this study was to identify members of the IGF protein family other than IGF2 and IGF1R that play a role in sprouting angiogenesis, based on experimental models of angiogenesis in vitro. As serum contains significant 
Fig. 5 IGFBP3 is essential for IGF2-mediated sprouting angiogenesis. HUVECs were cultured in the absence of serum and in the presence of either siNT, siIGFBP3 or siIGF1R $(\mathbf{a}-\mathbf{c}, \mathbf{f})$ and in the presence or absence of exogenous IGFB3 and/or IGF2 (d, e). a Number of sprouts and $\mathbf{b}$ average length of sprouts $(\mu \mathrm{m})$ per spheroid after knockdown of IGFBP3 in the presence or absence of exogenous IGF2; $\mathbf{c}$ corresponding representative images.

Scale bars represent $200 \mu \mathrm{m}$. d Number of sprouts and $\mathbf{e}$ average length of sprouts $(\mu \mathrm{m})$ per spheroid in the presence and absence of exogenous IGFBP3 and/or exogenous IGF2. f Flow cytometric analysis of the percentages of $\mathrm{CD} 34^{+}$tip cells in HUVEC cultures in the presence or absence of siIGFBP3 and in the presence or absence of exogenous IGF2. Medium of spheroids was supplemented with VEGF to maintain sprouting and to reduce EC apoptosis. Data of sprout numbers and length are shown as the mean \pm standard deviation after factor correction. Flow cytometric data are presented as average percentages of CD34 ${ }^{+}$HUVECs. * $\mathrm{P}<0.05$, $* * \mathrm{P}<0.01$ as compared to control or siNT treatment using a Student's t-test $(n=3)$
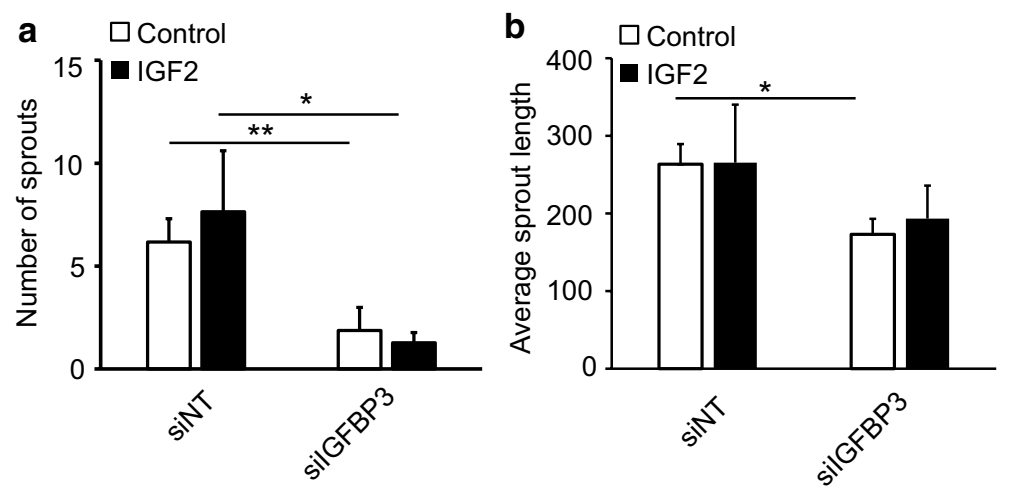

c
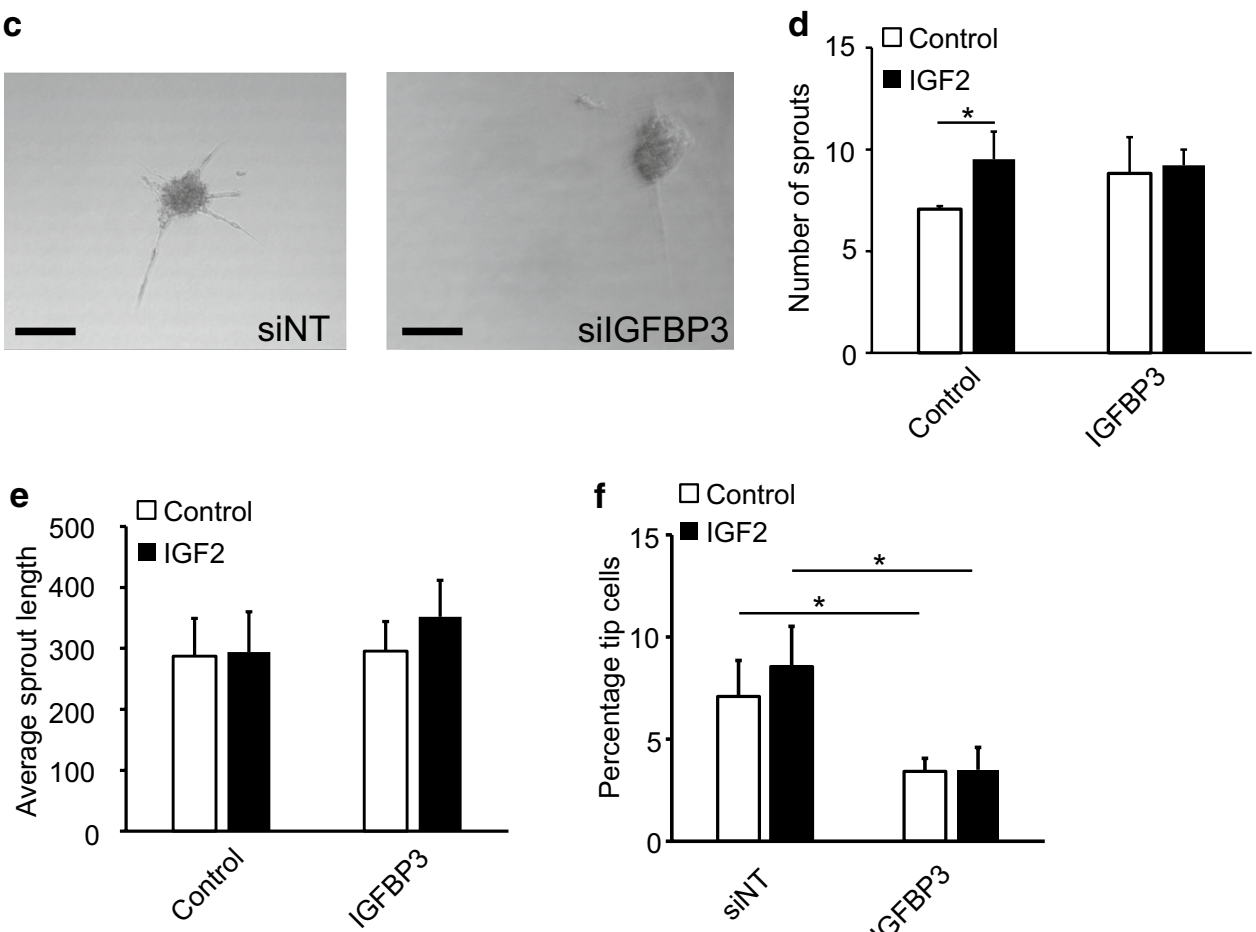

levels of IGF1, IGF2 and IGFBPs [4, 21, 22], we compared sprouting angiogenesis of HUVECs in vitro in the presence or absence of $20 \%$ serum. We observed that in the absence of serum knockdown of IGF2 affected sprouting more markedly than in the presence of serum, most likely due to the presence of IGF2 in serum. Live-cell imaging showed that IGF2 is necessary for the initiation of sprouting [2], and that in the absence of IGF2, tip cells emerge from spheroids but do not have the capacity to maintain their phenotype for sprouting. These findings indicate that local levels of IGF2, produced by the tip cells, are essential for efficient sprouting.

The most likely other candidate proteins present in serum for local regulation of IGF2 signaling are the IGFBPs, which regulate IGF bioavailability, and of which IGFBP3 and IGFBP4 have the highest affinities for IGF2 [38]. In addition, IGFBP4 is highly expressed in tip cells [28]. We indeed found that IGFBP3 and IGFBP4 expression in tip cells affected IGF2 signaling, in a positive and negative fashion, respectively.

It has been hypothesized that IGFBP4 acts as an extracellular reservoir for IGF1 and IGF2 [28]. IGFBP4 binds and inhibits the activity of these IGF ligands. Local degradation of IGFBP4 releases the IGF ligand, which then becomes available for receptor binding and activation of downstream signaling [39]. Our study is in agreement with this hypothesis, as the interpretation of our data is that IGFBP4 is mainly produced by tip cells to regulate local concentrations of IGF2, which by itself maintains the tip cell phenotype and enhances sprouting angiogenesis. IGFBP3, on the other hand, forms a complex with ALS and either IGF1 or IGF2, and acts as a carrier of these ligands to prevent their degradation $[38,40]$. It has been reported that IGFBP3 has pro- and anti-angiogenic roles [41], but we have found a clear stimulatory role of IGFBP3 in sprouting angiogenesis. 

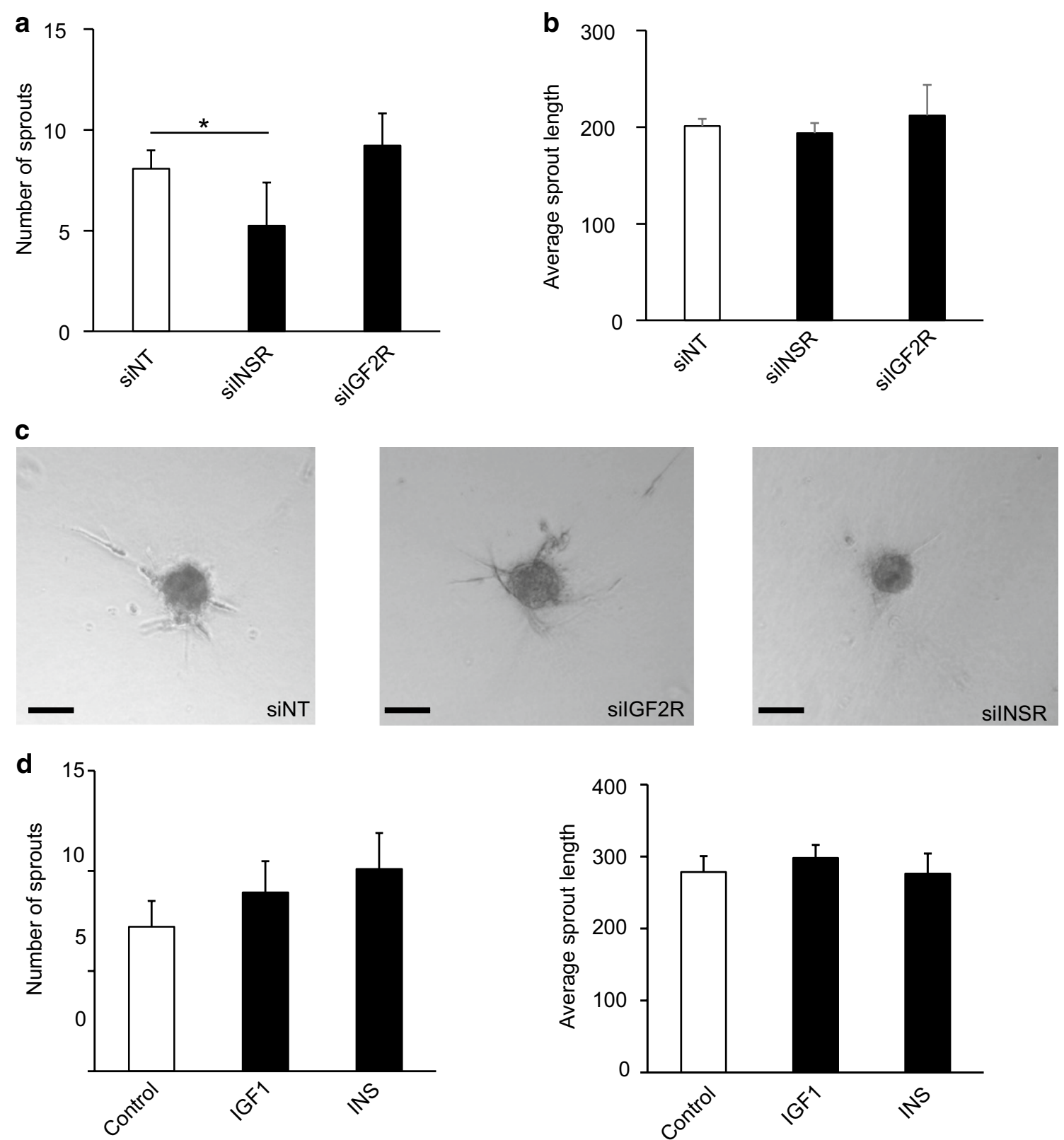

Fig. 6 Involvement of other receptors besides IGF1R on sprouting angiogenesis. HUVECs were cultured in the absence of serum and in the presence of either siNT, siIGF2R or siINSR and in the presence or absence of exogenous IGF2. a Number of sprouts and $\mathbf{b}$ average length of sprouts $(\mu \mathrm{m})$ per spheroid after knockdown of $I G F 2 R$ or INSR; c corresponding representative images. Scale bars represent

It has been reported that IGFBP3 can bind to the cell surface, which induces conformational changes that decrease the IGF-binding affinity to IGFBP3, but increases affinity of IGF ligands for IGF1R [42, 43], thereby enhancing downstream signaling.

We also investigated whether the other ligands and receptors of the IGF family played a role in sprouting angiogenesis. Since expression of IGF1 is barely detectable

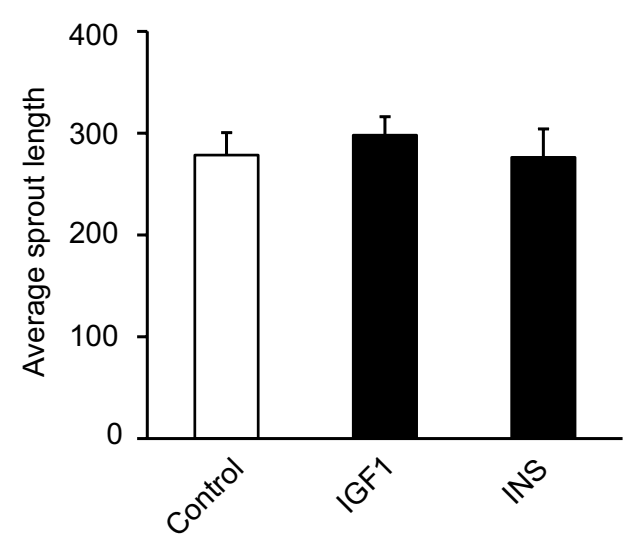

$200 \mu \mathrm{m}$. d Numbers of sprouts and e average length of sprouts $(\mu \mathrm{m})$ per spheroid in the presence or absence of IGF1 or INS. Medium of spheroids was supplemented with VEGF to maintain sprouting and to reduce EC apoptosis. Data of sprout numbers and length are shown as the mean \pm standard deviation after factor correction. $* \mathrm{P}<0.05$ as compared to control or siNT treatment using a Student's t-test $(n=3)$

in HUVECs and was absent in serum-free medium, we conclude that it did not contribute. This is consistent with the literature, since it was found that addition of IGF1 to HUVECs contributed to vessel maintenance and not to angiogenesis [44]. This conclusion is also in agreement with the role of IGF1 in retinopathy of prematurity, which is a disease in infants in which neovascularization of retinal vessels does not occur until serum concentrations 
of IGF1 have reached a threshold [45, 46]. Only when serum IGF1 levels are high, retinal blood vessels are being formed and cause damage to the retina.

Exogenous INS also did not affect sprouting angiogenesis, but knockdown of INSR reduced sprouting angiogenesis. INSR exists as two splice variants: INSR-A and INSR-B, of which the INSR-A isoform has recently been shown to be important in tumor angiogenesis, and preferably binds IGF2 [16]. Our INSR knockdown experiments show reduced sprouting and also reduced effects of IGF2 on sprouting angiogenesis. Our findings, in combination with data in the literature, indicate that (1) INSR is involved in angiogenesis in mice and chicken $[17,47]$ and (2) INSR and IGF1R can form heterodimers to mediate downstream signaling $[47,48]$. Therefore, we conclude that INSR is involved in IGF2-induced sprouting angiogenesis, together with or independently of IGF1R. On the other hand, IGF2R acts as an extracellular sink for IGF2 $[5,6,49]$. However, the lack of effect of $I G F 2 R$ knockdown on sprouting from spheroids indicates that its role in sprouting angiogenesis is not strong.

Limitations of this study include the lack of in vivo experiments to support our in vitro findings. It would be interesting to study tip cells in vivo in, for example, mouse retinas to confirm our in vitro data. Experiments showing the presence of IGF2 around tip cells with the use of in situ hybridization would add evidence to our hypothesis of IGF2 being locally produced to maintain the tip cell phenotype. We have so far not managed to show the presence of IGF2 in vivo, which may be due to its very small molecular size of $7.5 \mathrm{kDa}$. Another concern is the comparison of concentrations of growth factors and binding proteins that we used in our experiments and their serum equivalents. For VEGF, the concentration that we used in the serum-free experiments $(25 \mathrm{ng} / \mathrm{mL}$ ) was similar to the concentration in medium supplemented with $20 \%$ human serum $(22-45 \mathrm{ng} / \mathrm{mL})$ [50-52]. However, the concentrations of IGF2 and IGFBP3 were relatively low in our experimental setup as compared to medium supplemented with $20 \%$ serum and especially that of IGFBP3 [24, 53-55]. A comparison of these concentrations can only be performed with caution because of the interactions between these proteins and other IGF family members [11]. In the circulation, virtually all IGF1 and IGF2 is bound to IGFBP3 and ALS and to a lesser extent to IGFBP4 [4]. This means that higher concentrations in serum do not mean that more protein is available. Furthermore, production of IGF 2 by endothelial cells is limited, and thus the low concentrations of IGF2 and IGFBP 3 that we applied in our experimental setup should be sufficient. Others have shown significant effects of IGFBP3 at the concentration that we used [25]. We applied a high concentration of exogenous IGFBP4 (40 ng/mL) when compared to medium with $20 \%$ serum ( $8 \mathrm{ng} / \mathrm{mL}$ on average [54]) to show that IGFBP4 had no effects on sprouting.

\section{Conclusion}

Our findings suggest that the IGF family has a major role in sprouting angiogenesis and tip cell maintenance, partly by autocrine mechanisms. Tip cells secrete IGF2, which maintains their phenotype and allows sprouting angiogenesis by signaling via IGF1R and INSR, but not via IGF2R, and tip cells secrete the IGF2 inhibitor IGFBP4, which acts as a negative local regulator, while tip cells and nontip cells secrete IGFBP3, acting as a positive local regulator of the IGF2-induced tip cell maintenance and sprouting angiogenesis orchestrated by tip cells.

Acknowledgements Microscopy and flow cytometry experiments were performed at the Core Facility Cellular Imaging, Department of Medical Biology of the Academic Medical Centre, Amsterdam, The Netherlands. The authors were supported by the following foundations: MGD, YIH, RPK, CJFvN, IK, ROS: Landelijke Stichting voor Blinden en Slechtzienden, Algemene Nederlandse Vereniging Ter Voorkoming Van Bindheid, Stichting Blindenpenning, Novartisfonds, and the ODAS stichting, that contributed through UitZicht (Grant UitZicht 2013-12). Other grants were provided by Rotterdamse Stichting Blindenbelangen (Grant B20130006), and Stichting Nederlands Oogheelkundig Onderzoek (Grant 2013-04).

Author contributions MGD designed and performed experiments, analyzed data and wrote the manuscript. IK and ROS designed experiments. YIH and RPK performed experiments. ROS, CJFvN and IK contributed to the discussion and editing of the manuscript. All authors have read and approved the final manuscript.

Open Access This article is licensed under a Creative Commons Attribution 4.0 International License, which permits use, sharing, adaptation, distribution and reproduction in any medium or format, as long as you give appropriate credit to the original author(s) and the source, provide a link to the Creative Commons licence, and indicate if changes were made. The images or other third party material in this article are included in the article's Creative Commons licence, unless indicated otherwise in a credit line to the material. If material is not included in the article's Creative Commons licence and your intended use is not permitted by statutory regulation or exceeds the permitted use, you will need to obtain permission directly from the copyright holder. To view a copy of this licence, visit http://creativecommons.org/licenses/by/4.0/.

\section{References}

1. Gerhardt H, Golding M, Fruttiger M, Ruhrberg C, Lundkvist A, Abramsson A, Jeltsch M, Mitchell C, Alitalo K, Shima D, Betsholtz C (2003) VEGF guides angiogenic sprouting utilizing endothelial tip cell filopodia. J Cell Biol 161:1163-1177. https ://doi.org/10.1083/jcb.200302047

2. Dallinga MG, Yetkin-Arik B, Kayser RP, Vogels IMC, NowakSliwinska P, Griffioen AW, van Noorden CJF, Klaassen I, Schlingemann RO (2018) IGF2 and IGF1R identified as novel 
tip cell genes in primary microvascular endothelial cell monolayers. Angiogenesis 21:823-836. https://doi.org/10.1007/ s10456-018-9627-4

3. Dallinga MG, Boas SEM, Klaassen I, Merks RHM, Van Noorden CJF, Schlingemann RO (2015) Tip cells in angiogenesis. eLS. https://doi.org/10.1002/9780470015902a0025977

4. Bach LA (2015) Endothelial cells and the IGF system. J Mol Endocrinol 54:R1-13. https://doi.org/10.1530/JME-14-0215

5. Harris LK, Westwood M (2012) Biology and significance of signalling pathways activated by IGF-II. Growth Factors 30:1-12. https://doi.org/10.3109/08977194.2011.640325

6. Herr F, Liang OD, Herrero J, Lang U, Preissner KT, Han VK, Zygmunt M (2003) Possible angiogenic roles of insulin-like growth factor II and its receptors in uterine vascular adaptation to pregnancy. J Clin Endocrinol Metab 88:4811-4817. https:// doi.org/10.1210/jc.2003-030243

7. Soos MA, Siddle K (1989) Immunological relationships between receptors for insulin and insulin-like growth factor I. J Biochem 263:553-563

8. Moxham CP, Duronio V, Jacobs S (1989) Insulin-like growth factor I receptor B-subunit heterogeneity. J Biol Chem 264:13238-13244

9. Kasuya J, Paz IB, Maddux BA, Goldfine ID, Hefta SA, FujitaYamaguchi Y (1993) Characterization of human placental insulinlike growth factor-I/insulin hybrid receptors by protein microsequencing and purification. Biochemistry 32:13531-13536. https ://doi.org/10.1021/bi00212a019

10. Efstratiadis A (1998) Genetics of mouse growth. Int J Dev Biol 42:955-976

11. Massoner P, Ladurner-Rennau M, Eder IE, Klocker H (2010) Insulin-like growth factors and insulin control a multifunctional signalling network of significant importance in cancer. Br J Cancer 103:1479-1484. https://doi.org/10.1038/sj.bjc.6605932

12. van Beijnum JR, Pieters W, Nowak-Sliwinska P, Griffioen AW (2017) Insulin-like growth factor axis targeting in cancer and tumour angiogenesis- the missing link. Biol Rev Camb Philos Soc 92:1755-1768. https://doi.org/10.1111/brv.12306

13. Guidry C, Feist R, Morris R, Hardwick CW (2004) Changes in IGF activities in human diabetic vitreous. Diabetes 53:2428-2435

14. Lofqvist C, Willett KL, Aspegren O, Smith AC, Aderman CM, Connor KM, Chen J, Hellstrom A, Smith LE (2009) Quantification and localization of the IGF/insulin system expression in retinal blood vessels and neurons during oxygen-induced retinopathy in mice. Investig Ophthalmol Vis Sci 50:1831-1837. https://doi. org/10.1167/iovs.08-2903

15. Ritter MR, Dorrell MI, Edmonds J, Friedlander SF, Friedlander M (2002) Insulin-like growth factor 2 and potential regulators of hemangioma growth and involution identified by large-scale expression analysis. Proc Natl Acad Sci USA 99:7455-7460. https ://doi.org/10.1073/pnas.102185799

16. LeRoith D, Roberts CT (2003) The insulin-like growth factor system and cancer. Cancer Lett 195:127-137. https://doi.org/10.1016/ s0304-3835(03)00159-9

17. Nowak-Sliwinska P, van Beijnum JR, Huijbers EJM, Gasull PC, Mans L, Bex A, Griffioen AW (2019) Oncofoetal insulin receptor isoform A marks the tumour endothelium; an underestimated pathway during tumour angiogenesis and angiostatic treatment. Br J Cancer 120:218-228. https://doi.org/10.1038/s4141 6-018-0347-8

18. Correira da Silva G, Bell SC, Pringle JH, Teixeira N (1999) Expression of mRNA encoding insulin-like growth factors I and II by uterine tissues and placenta during pregnancy in the rat. Mol Reprod Dev 53:294-305

19. Tollefsen SE, Sadow JL, Rotwein P (1989) Coordinate expression of insulin-like growth factor II and its receptor during muscle differentiation. Proc Natl Acad Sci USA 86:1543-1547
20. Lee CY, Rechler MM (1995) Formation of 150-kDa binary complexes of insulin-like growth factor binding protein-3 and the acid-labile subunit in vitro and in vivo. Prog Growth Factor Res 6:241-251

21. Wang J, Li Y, Deng M, Jiang H, Guo L, Zhou J, Ruan B (2017) Serum insulin-like growth factor-1 and its binding protein 3 as prognostic factors for the incidence, progression, and outcome of hepatocellular carcinoma: a systematic review and metaanalysis. Oncotarget 8:81098-81108

22. Gao Y, Katki H, Graubard B, Pollak M, Martin M, Tao Y, Schoen RE, Church T, Hayes RB, Greene MH, Berndt SI (2012) Serum IGF1, IGF2 and IGFBP3 and risk of advanced colorectal adenoma. Int J Cancer 131:E105-113. https://doi.org/10.1002/ ijc. 26438

23. Greenall SA, Bentley JD, Pearce LA, Scoble JA, Sparrow LG, Bartone NA, Xiao X, Baxter RC, Cosgrove LJ, Adams TE (2013) Biochemical characterization of individual human glycosylated pro-insulin-like growth factor (IGF)-II and big-IGF-II isoforms associated with cancer. J Biol Chem 288:59-68. https://doi. org/10.1074/jbc.M112.432013

24. Espelund U, Gronbaek H, Villadsen GE, Simonsen K, Vestergaard PF, Jorgensen JO, Flyvbjerg A, Vilstrup H, Frystyk J (2015) The circulating IGF system in hepatocellular carcinoma: the impact of liver status and treatment. Growth Horm IGF Res 25:174-181. https://doi.org/10.1016/j.ghir.2015.05.002

25. Chang KH, Chan-Ling T, McFarland EL, Afzal A, Pan H, Baxter LC, Shaw LC, Caballero S, Sengupta N, Li Calzi S, Sullivan SM, Grant MB (2007) IGF binding protein-3 regulates hematopoietic stem cell and endothelial precursor cell function during vascular development. Proc Natl Acad Sci USA 104:10595-10600. https ://doi.org/10.1073/pnas.0702072104

26. Contois LW, Nugent DP, Caron JM, Cretu A, Tweedie E, Akalu A, Liebes L, Friesel R, Rosen C, Vary C, Brooks PC (2012) Insulinlike growth factor binding protein-4 differentially inhibits growth factor-induced angiogenesis. J Biol Chem 287:1779-1789. https ://doi.org/10.1074/jbc.M111.267732

27. Smith YE, Toomey S, Napoletano S, Kirwan G, Schadow C, Chubb AJ, Mikkelsen JH, Oxvig C, Harmey JH (2018) Recombinant PAPP-A resistant insulin-like growth factor binding protein 4 (dBP4) inhibits angiogenesis and metastasis in a murine model of breast cancer. BMC Cancer 18:1016. https://doi.org/10.1186/ s12885-018-4950-0

28. Ryan AJ, Napoletano S, Fitzpatrick PA, Currid CA, O’Sullivan NC, Harmey JH (2009) Expression of a protease-resistant insulinlike growth factor-binding protein-4 inhibits tumour growth in a murine model of breast cancer. Br J Cancer 101:278-286. https:// doi.org/10.1038/sj.bjc.6605141

29. Siemerink MJ, Klaassen I, Vogels IM, Griffioen AW, Van Noorden CJ, Schlingemann RO (2012) CD34 marks angiogenic tip cells in human vascular endothelial cell cultures. Angiogenesis 15:151163. https://doi.org/10.1007/s10456-011-9251-z

30. van der Schaft DWJ, Toebes EAH, Haseman JR, Mayo KH, Griffioen AW (2000) Bactericidal/permeability-increasing protein (BPI) inhibits angiogenesis via induction of apoptosis in vascular endothelial cells. Blood 96:176-181

31. Korff T, Augustin HG (1998) Integration of endothelial cells in multicellular spheroids prevents apoptosis and induces differentiation. J Cell Biol 143:1341-1352

32. Nowak-Sliwinska P, Alitalo K, Allen E, Anisimov A, Aplin AC, Auerbach R, Augustin HG, Bates DO, van Beijnum JR, Bender RHF, Bergers G, Bikfalvi A, Bischoff J, Bock BC, Brooks PC, Bussolino F, Cakir B, Carmeliet P, Castranova D, Cimpean AM, Cleaver O, Coukos G, Davis GE, De Palma M, Dimberg A, Dings RPM, Djonov V, Dudley AC, Dufton NP, Fendt SM, Ferrara N, Fruttiger M, Fukumura D, Ghesquiere B, Gong Y, Griffin RJ, Harris AL, Hughes CCW, Hultgren NW, Iruela-Arispe ML, Irving M, 
Jain RK, Kalluri R, Kalucka J, Kerbel RS, Kitajewski J, Klaassen I, Kleinmann HK, Koolwijk P, Kuczynski E, Kwak BR, Marien K, Melero-Martin JM, Munn LL, Nicosia RF, Noel A, Nurro J, Olsson AK, Petrova TV, Pietras K, Pili R, Pollard JW, Post MJ, Quax PHA, Rabinovich GA, Raica M, Randi AM, Ribatti D, Ruegg C, Schlingemann RO, Schulte-Merker S, Smith LEH, Song JW, Stacker SA, Stalin J, Stratman AN, Van de Velde M, van Hinsbergh VWM, Vermeulen PB, Waltenberger J, Weinstein BM, Xin H, Yetkin-Arik B, Yla-Herttuala S, Yoder MC, Griffioen AW (2018) Consensus guidelines for the use and interpretation of angiogenesis assays. Angiogenesis 21:425-532. https://doi. org/10.1007/s10456-018-9613-X

33. Chieco P, Jonker A, De Boer BA, Ruijter JM, Van Noorden CJ (2013) Image cytometry: protocols for $2 \mathrm{D}$ and 3D quantification in microscopic images. Prog Histochem Cytochem 47:211-333. https://doi.org/10.1016/j.proghi.2012.09.001

34. van Duinen V, Zhu D, Ramakers C, van Zonneveld AJ, Vulto P, Hankemeier T (2019) Perfused 3D angiogenic sprouting in a highthroughput in vitro platform. Angiogenesis 22:157-165. https:// doi.org/10.1007/s10456-018-9647-0

35. Preibisch S, Saalfeld S, Tomancak P (2009) Globally optimal stitching of tiled 3D microscopic image acquisitions. Bioinformatics 25:1463-1465. https://doi.org/10.1093/bioinformatics/btp184

36. Ruijter JM, Thygesen HH, Schoneveld OJ, Das AT, Berkhout B, Lamers WH (2006) Factor correction as a tool to eliminate between-session variation in replicate experiments: application to molecular biology and retrovirology. Retrovirology 3:2. https ://doi.org/10.1186/1742-4690-3-2

37. Yetkin-Arik B, Vogels IMC, Neyazi N, van Duinen V, Houtkooper RH, van Noorden CJF, Klaassen I, Schlingemann RO (2019) Endothelial tip cells in vitro are less glycolytic and have a more flexible response to metabolic stress than non-tip cells. Sci Rep 9:10414. https://doi.org/10.1038/s41598-019-46503-2

38. Cohick WS, Clemmons DR (1993) The insulin-like growth factors. Annu Rev Physiol 55:131-153

39. Conover CA, Bale LK, Overgaard MT, Johnstone EW, Laursen UH, Fuchtbauer EM, Oxvig C, van Deursen J (2004) Metalloproteinase pregnancy-associated plasma protein A is a critical growth regulatory factor during fetal development. Development 131:1187-1194. https://doi.org/10.1242/dev.00997

40. Ranke MB (2015) Insulin-like growth factor binding-protein-3 (IGFBP-3). Best Pract Res Clin Endocrinol Metab 29:701-711. https://doi.org/10.1016/j.beem.2015.06.003

41. Chao W, D'Amore PA (2008) IGF2: epigenetic regulation and role in development and disease. Cytokine Growth Factor Rev 19:111-120. https://doi.org/10.1016/j.cytogfr.2008.01.005

42. Clemmons DR, Busby W, Clarke JB, Parker A, Duan C, Nam TJ (1998) Modifications of insulin-like growth factor binding proteins and their role in controlling IGF actions. Endocr $\mathbf{J}$ 45(Suppl):S1-S8

43. De Mellow JSM, Baxter RC (1988) Growth Hormone-dependent insulin-like growth factor (IGF) binding protein both inhibits and potentiates IGF-1 stimulated DNA synthesis in human skin fibroblasts. Biochem Bioph Res Co 156:199-204

44. Jacobo SM, Kazlauskas A (2015) Insulin-like growth factor 1 (IGF-1) stabilizes nascent blood vessels. J Biol Chem 290:63496360. https://doi.org/10.1074/jbc.M114.634154

45. Hellstrom A, Perruzzi C, Ju M, Engstrom E, Hard AL, Liu JL, Albertsson-Wikland K, Carlsson B, Niklasson A, Sjodell L,
LeRoith D, Senger DR, Smith LE (2001) Low IGF-I suppresses VEGF-survival signaling in retinal endothelial cells: direct correlation with clinical retinopathy of prematurity. Proc Natl Acad Sci USA 98:5804-5808. https://doi.org/10.1073/pnas.101113998

46. Hellstrom A, Carlsson B, Niklasson A, Segnestam K, Boguszewski M, De La Cerda L, Savage M, Svensson E, Smith L, Weinberger D, Albertsson Wikland K, Laron Z (2002) IGF-1 is critical for normal vascularization of the human retina. J Clin Endocr Metab 87:3413-3416

47. Kondo T, Vicent D, Suzuma K, Yanagisawa M, King GL, Holzenberger M, Kahn CR (2003) Knockout of insulin and IGF-1 receptors on vascular endothelial cells protects against retinal neovascularization. J Clin Investig 111:1835-1842. https://doi.org/10.1172/ jci200317455

48. Belfiore A, Frasca F, Pandini G, Sciacca L, Vigneri R (2009) Insulin receptor isoforms and insulin receptor/insulin-like growth factor receptor hybrids in physiology and disease. Endocr Rev 30:586-623. https://doi.org/10.1210/er.2008-0047

49. Ludwig $\mathrm{T}$ (1995) Roles for mannose-6-phosphate receptors in lysosomal enzyme sorting, IGF-II binding and clathrin-coat assembly. Trends Cell Biol 5:202-206

50. Cigrovski Berkovic M, Cacev T, Catela Ivkovic T, Marout J, Ulamec M, Zjacic-Rotkvic V, Kapitanovic S (2016) High VEGF serum values are associated with locoregional spread of gastroenteropancreatic neuroendocrine tumors (GEP-NETs). Mol Cell Endocrinol 425:61-68. https://doi.org/10.1016/j.mce.2016.01.013

51. Hayran Y, Lay I, Mocan MC, Bozduman T, Ersoy-Evans S (2019) Vascular endothelial growth factor gene polymorphisms in patients with rosacea: a case-control study. J Am Acad Dermatol 81:348-354. https://doi.org/10.1016/j.jaad.2019.03.055

52. Ren H, Shao Y, Ma X, Yang M, Liu Y, Wang Q (2019) Expression levels of serum vasohibin-1 and other biomarkers in type 2 diabetes mellitus patients with different urinary albumin to creatinine ratios. J Diabetes Complicat 33:477-484. https://doi. org/10.1016/j.jdiacomp.2019.04.008

53. Ji Y, Wang Z, Chen H, Zhang L, Zhuo F, Yang Q (2018) Serum from chronic hepatitis $\mathrm{B}$ patients promotes growth and proliferation via the IGF-II/IGF-IR/MEK/ERK signaling pathway in hepatocellular carcinoma cells. Cell Physiol Biochem 47:39-53. https ://doi.org/10.1159/000489744

54. Kubasiak JC, Seder CW, Pithadia R, Basu S, Fhied C, Phillips WW, Daly S, Shersher DD, Yoder MA, Chmielewski G, Edell ES, Maldonado F, Liptay MJ, Borgia JA (2015) Value of circulating insulin-like growth factor-associated proteins for the detection of stage I non-small cell lung cancer. J Thorac Cardiovasc Surg 149:727-734. https://doi.org/10.1016/j.jtcvs.2014.08.085. discussion 734

55. Kalledsoe L, Dragsted LO, Hansen L, Kyro C, Gronbaek H, Tjonneland A, Olsen A (2019) The insulin-like growth factor family and breast cancer prognosis: a prospective cohort study among postmenopausal women in Denmark. Growth Horm IGF Res 44:33-42. https://doi.org/10.1016/j.ghir.2018.12.003

Publisher's Note Springer Nature remains neutral with regard to jurisdictional claims in published maps and institutional affiliations. 